\title{
Veidenbaums atdzejojumos. Izlase
}

Māras Grudules un Mariana Rižija

sakārtojums un komentāri

\section{Īsumā par Veidenbauma dzejas atdzejojumiem citās valodās}

Saskaṇā ar pieejamajiem avotiem ir apzināti Eduarda Veidenbauma dzejas atdzejojumi 12 valodās - 34 atdzejotāju darbs.

\begin{tabular}{|l|l|}
\hline \multicolumn{1}{|c|}{ Valoda } & \multicolumn{1}{c|}{ Atdzejotāji } \\
\hline Angḷu & Viljams Klēsmanis Metjūss \\
\hline Baltkrievu & Al̦ess Bačila \\
\hline Čehu & Radegasts Paroleks \\
\hline Esperanto & Nikolajs Ķurzēns \\
\hline Franču & Elza Stērste \\
\hline Igauṇu & Ains Kāleps, Contra, Matss Trāts \\
\hline Krievu & $\begin{array}{l}\text { Vladimirs Aleksejevs, Dāvids Brodskis, Vladimirs Bugajevskis, Leonīds } \\
\text { Čerevičņiks, Arsēnijs Formakovs, Grigorijs Gorskis, Igors Grigorjevs, } \\
\text { Fēlikss Kacs, Samuils Maršaks, Isaakijs Mordvinovs, Vladimirs Nevskis, } \\
\text { Jel̦ena Sireiščikova, Vadims Šefners, Sergejs Šervinskis, Viktors } \\
\text { Tretjakovs, Edvarts Virza }\end{array}$ \\
\hline Lietuviešu & Vigmants Butkus, Juḷus Janonis, Eugenijs Matuzēvičs, Justs Paleckis \\
\hline Poḷu & Stan̦islavs Černiks \\
\hline Ukrain̦u & Kosts Overčenko \\
\hline Ungāru & Tandori Deže, Gābors Garai \\
\hline Vācu & Matiass Knolls, Karls Frīdrihs Kohs \\
\hline
\end{tabular}

Visvairāk Eduards Veidenbaums ir atdzejots krievu valodā. Pirmais līdz šim vispār zināmais atdzejojums - dzejolis "Kā gulbji balti padebeši iet" ar nosaukumu В болотах ["Purvos"] ir tapis jau 1907. gadā un publicēts gadu vēlāk Pēterburgā krievu iknedēḷas kultūras žurnālā Север ${ }^{1}$. Atdzejotājs ir 1905. gada streiku

1 1908, № 50, c. 758. 
organizētājs, Valkas krievu valodas skolotājs Isaakijs Mordvinovs. Šis tulkojums ir apzināts nesen. ${ }^{2}$

Veidenbauma atdzejojumu popularitāti krievu valodā nosaka vairāki faktori, starp kuriem galvenie ir, pirmkārt, latviešu dekadentu ciešie sakari ar krievu simbolisma izcilākajiem pārstāvjiem 20. gadsimta sākumā. Savstarpējo interesi un sadarbību apliecina 1916. gadā izdotā latviešu dzejas antolog̣ija Сборник латышской литературы ["Latviešu literatūras krājums"]. Tajā Veidenbauma dzeju pēc parindeniem atdzejojusi Jel̦ena Sireiščikova un Sergejs Šervinskis. ${ }^{3}$ Latviešu atdzejojumus tolaik pārrauga, nereti arī pats tos pamatīgi koriĝèdams, Valerijs Brjusovs. Šervinskis atmiṇās raksta: "N̦em parindeṇus, strādā pēc izjūtas un mēǵinot uzminēt. Bet aiz muguras "metra" autoritāte un vērīgums." "Saglabājušies krājuma manuskripti un Brjusova sarakste iepriekš rakstīto apliecina. Tā, piemēram, īpaši bargi Brjusovs labojis savas draudzenes Jel̦enas Sireiščikovas atdzejojumus - no Veidenbauma programmatiskā dzejoḷa "Mosties, mosties reiz, svabadais gars" krievu varianta viņš paturējis tikai trīs Sireiščikovas rindas, savukārt dzejoḷa "Es atceros rožainos laikus" krievu tulkojumu Brjusovs pilnībā radījis pats, kaut arī vēlāk tas publicēts ar Sireiščikovas kā atdzejotājas vārdu. ${ }^{5}$ Sireiščikovas un Šervinska atdzejojumi publicēti arī vēlāk - tie pārceḷo uz starpkaru perioda Latvijas krievu presi un tūlìt pēc Otrā pasaules kara - arī uz padomju presi. Zīmīgi, ka Veidenbaumu krieviski 20. gadsimta 20. gadu pirmajā pusē atdzejojis arī mūsu pašu izcilais dzejnieks Edvarts Virza. ${ }^{6}$

30. gados trīs Veidenbauma dzejoḷus krieviski atdzejojis arī žurnālists, dzejnieks un atdzejotājs Viktors Tretjakovs, kurš 20. gadsimta sākumā bija viens no krievu modernistu grupējuma "Dzejnieku cehs" (Цех поэтов) dalībniekiem,

2 Par to plašāk: Спроге, Л. В.; Царькова, Т. С. «Некий Мордвинов по-русски перевел наши стихи»: о переводах латышских поэтов в начале XX века. Русская литература, 2016, № 2, c. 141-147. http://lib2.pushkinskijdom.ru/Media/Default/PDF/RusLiteratura/ \%D0\%A0\%D0\%9B_2_2016.pdf [sk. 24.05.2020.]

3 Krājumā iekḷauti pieci Veidenbauma dzejoḷi: Когда я молодъ былъ... [Kad es jauns biju... dzej. "Reiz zal,oja jaunība, cerības plauka..." tulk. J. Sireiščikova]; Изъ мира, словно сонъ, уходятъ поколъния... [No pasaules kā sapnis, aiziet paaudzes... dzej. "Kā sapn,i no pasaules dzimumi zūd...” tulk. J. Sireiščikova]; Нъть правды на землъ... [Nav taisnības uz zemes... dzej. "Virs zemes nav taisnïbas..." tulk. J. Sireiščikova]; И дождь надъ грязью улицъ... [Un lietus pār netīrām ielām... dzej. "Pa ielām dubḷainām līst lietus..." tulk. S. Šervinskis]; Я помню счастливые годы... [Es atceros laimīgos gadus... dzej. "Es atminos rožainos laikus...", tulk. J. Sireiščikova]; Проснись, проснись, свободный духъ... [Mosties, mosties, brīvais gars... "Mosties, mosties reiz, svabadais gars..." tulk. J. Sireiščikova].

4 Берут подстрочники, работают на ощупь, наугад. Но за спиной авторитет и проницательность «мэтра». Ускова, О. Валерий Брюсов и латышская поэзия. Даугава, 1987, № 5, c. 115.

5 Turpat, 115. un 118.-119. lpp.

6 Всё мутно от лунного света... [Viss miglains mēness gaismā... dzej. "Pie debesīm mēness spīd bālais..."]; ar virsrakstu Поэтy [Dzejniekam] dzejolis "Kam velti dārgo laiku tērē..." (К какому ты стремишься благу... [Pēc kāda labuma tu dzenies...]), Где журчит в тени у ската... [Kur ēnā burbuḷo pie nogāzes...] dzej. "Upes malu liepas ēno..."]. Рижский курьер, 1924, 24 февр. 
Mihaila Kuzmina draugs, ang̣̣u dzejnieka Viljama Vērdsverta atdzejotājs. Krievijas revolūcijas un tai sekojošā Pilsoṇu kara dēḷ Tretjakovs pēc Krievijas Mākslas akadēmijas absolvēšanas 1921. gadā emigrēja uz Latviju un iemācījās latviešu valodu. Tretjakova atdzejotie Veidenbauma darbi publicēti gan Latvijas krievu presē, gan uzṇemti viṇa paša sastādītajā un tulkotajā latviešu dzejas antologijāā krievu valodā (1931). Dzejoli “Jau ziediem rotātas plavas” 1939. gadā krieviski atdzejojis arī Liepājā dzimušais krievu dzejnieks, vēlāk - viens no Daugavpils krievu kopienas literātiem, prozaikis un tulkotājs Arsēnijs Formakovs. Starpkaru perioda Veidenbauma dzejas izlasei krievu valodā raksturīga dabas tematika un eksistenciāli motīvi.

Pēc Otrā pasaules kara nozīmīga loma Veidenbauma atdzejojumu tapšanā un to publicēšanā periodiskos izdevumos, kopkrājumos un antologijīās, kā arī atsevišḳās dzejas izlasēs ir viṇa iekḷaušanai padomju varas akceptēto dzejnieku kanonā. Jau 1953. gadā Rīgā iznāk Veidenbauma dzejas izlase Grigorija Gorska atdzejojumā. Gorskis ir Viskrievijas boḷševiku partijas biedrs kopš 1942. gada, kara korespondents un kopš 1945. gada dzīvo un strādā Latvijā - ir žurnālists Padomju Savienības informatīvajā aǵentūrā TASS, kā arī redaktors izdevniecībā "Liesma". Gorskis ir arī dzejnieks un vairāku populāru estrādes dziesmu autors un tulkotājs, to skaitā Aleksandra Kublinska dziesmas "Noktirne" [Ноктюрн]. Gorska atdzejojumā Rīgā 1953. gadā publicēta pirmā Veidenbauma dzejas izlase krievu valodā atsevišķā grāmatā. Tulkojums ir labs, Gorskis darbu turpina, un 1961. gadā Maskavā nāk klajā pilnīgs Veidenbauma dzejoḷu izdevums krieviski. Padomju dzejnieks Andrejs Balodis, nodēvējis Veidenbaumu par "revolūcijas dziesminieku", slavē Gorska darbu - precīzi atveidotās Veidenbaumam raksturīgās intonācijas, strofiku, iedziḷināšanos dzejiskajā domā un lielisko teksta izpratni. ${ }^{7}$ Arī kopumā laikmetā, kad latviešu literatūra ideoloğiskā spiediena dēḷ tiek tulkota steigā un tādēl nereti neuzmanīgi un pavirši, Gorska atdzejojumi saṇem uzslavas kā vieni no labākajiem. ${ }^{8}$

Dažādos laikposmos Veidenbaumu krievu valodā atdzejojuši kopumā 16 atdzejotāji, daži no vin,iem - tikai pāris dzejoḷu, turklāt, visticamākais, - no parindeņiem, starp viniem arī populārais padomju krievu bērnu rakstnieks Samuils Maršaks atdzejojis Veidenbauma četrrindi "Dievs ir laipnīgs: mācītājus". Tomēr šo atdzejojumu lokā īpaši izceḷama Leonīda Čerevičnika atdzejotā Veidenbauma dzejas izlase Cтихотворения ["Dzejolì"] (1980). Ukrainā dzimušais, kopš 1964. gada Rīgā dzīvojošais Čerevičniks ir viens no izdevniecības "Liesma” redaktoriem, kā arī Latvijas krievu kultūrai veltītā žurnāla «Даугава» dzejas nodaḷas ilggadējs vadītājs (1979-1996). Māris Čaklais, iznākšanas brīdī Čerevičnika atdzejojumus slavēdams, norāda, ka tos nepieciešams publicēt vēlreiz kopā ar tikko klajā nākušās Līvijas Volkovas monogrāfijas "Eduards Veidenbaums. Problēmas. Risinājumi. Hipotēzes" (1979) tulkojumu krievu valodā, ${ }^{9}$ tādējādi krievu lasītājam būtu iespējams iegūt pilnīgu priekšstatu ne tikai par Veidenbauma

7 Балодис, А. Певец революции. Ригас Балсс, 1961, № 292, 13 дек.

8 Sal. J. Č. [Jānis Čākurs?]. Latviešu grāmatas krievu valodā. Karogs, 1963, Nr. 2, 148. 1pp.; Auziňš, I. Kḷuvām bagātāki. Padomju Jaunatne, 1963, Nr. 131, 3. jūl. u. c.

9 Čaklais, M. "Ne ḷaudis, ne dievi, ne reklāmu stabi..." Karogs, 1981, Nr. 3, 136. lpp. 
dzeju, bet arī viṇa - "revolucionārā dzejnieka" - personību un uzskatiem. Tomēr tas nekad nenotiek. Čerevičnika atdzejojumus slavē arī Rolfs Ekmanis latviešu trimdas presē, un šì atzinība padomju laikā - 1981. gadā - nav novērtējama par zemu. ${ }^{10}$ Tomēr PSRS publicētajās latviešu dzejnieku antoloǵijās krievu valodā Veidenbauma dzeja visbiežāk tiek publicēta Gorska atdzejojumā, savukārt Latvijas krievu presē 80. gados Veidenbaums publicēts Čerevičnika atdzejojumā. Raksturīgi, ka pēc Latvijas neatkarības atjaunošanas vietējā krievu presē Veidenbauma dzeja parādās vai nu propadomiski noskan,otā humorista Fēliksa Kaca atdzejojumā, vai arī atkal tikai un vienīgi Grigorija Gorska tulkojumā.

Atdzejojumiem pārējās valodās ir epizodisks raksturs. Un tomēr līdz Otrajam pasaules karam Veidenbaums jau ir lasāms septin̄ās svešvalodās. Viṇa dzejoḷi ir iekḷauti latviešu lirikas izlasēs ang̣̣u un franču valodā. Plašāka Veidenbauma dzejas kopa tiek publicēta arī poliski. Atdzejotāji sarosās arī Eduarda Veidenbauma simtgadē - 1967. gadā pirmoreiz dzejnieks lasāms baltkrievu un ukraiṇu valodā, desmit gadus vēlāk viṇa dzejoḷi tiek iekḷauti arī latviešu literatūras antoloǵijā ungāru valodā. Mūsu kaimiṇu lietuviešu valodā Veidenbaums pirmoreiz atdzejots neilgi pirms Pirmā pasaules kara - dzejnieks Juḷus Janonis tulko plaši pazīstamo sacerējumu "Kā gulbji balti padebeši iet", diemžēl atdzejojums līdz mūsu dienām nav saglabājies. ${ }^{11}$ Igauniski Veidenbauma atdzejojumi zināmi tikai kopš 1967. gada. Tomēr tieši igauṇu kultūrtelpā interese par Veidenbaumu nav zudusi joprojām - starp pēdējo gadu atdzejojumiem kā īpašs notikums jāatzìmē dzejnieka un atdzejotāja Contras igauṇu valodā publicētā Veidenbauma izlase Mind ärge lugege ["Mani nelasiet"] (2014).

Tālāk sniegtajā atdzejojumu izlasē iekḷauti, iespējams, Eduarda Veidenbauma vispopulārākā dzejoḷa "Kā gulbji balti padebeši iet" atdzejojumi dažādās valodās.

Paldies par nenovērtējamo palīdzību Eduarda Veidenbauma dzejas atdzejojumu meklējumos Matiasam Knollam, Viktoram Meḷnikam un Vigmantam Butkum!

${ }^{10}$ Ekmanis, R. Dažas iezīmes pēdējo gadu rakstniecībā. Latvija Šodien, 1981, Nr. 9, 66. lpp.

${ }^{11}$ Stepin̄š, L. Eduards Veidenbaums cittautu lasîtājiem. Karogs, 1987, Nr. 10, 189. lpp. 
Kā gulbji balti padebeši iet, Tiem vēlētos es līdza tālu skriet, Tur tālumā, kur ziemas nepazīst, Kur rozes mūžam zied un nenovīst. Kam veltīgi laimību kāro tu, sirds? Met projām reiz cerības tumšajā kapā: No saulainām lejām ir mirstīgais škirts, Tam jādzīvo asaru dūksnājā slapjā, Kur dzelži un cirvji bez rimšanas klaudz, Pēc maizes, pēc pārtikas vergi kur sauc, No stiprākā samīts, vājāks kur lūst Un asins un sviedri ik dienas kur plūst.

No grām.: Veidenbaums, E. Dzeja. Rīga, 2005.
$* * *$
Jak bílých labutí je mraků let, do dálek za nimi bych béžel hned, do dálek tajemných, kde zimu neznají, kde růže nevadnou, jen vzkvétají. Proč po štěstí mé srdce toužíš jen? Nadějí zanech, do hrobu je vhod'! Od ráje pod sluncem jsi oddělen, v slzavém údolí dál s plačem chod', kde znějí zvuky pout a seker svist, kde chléb svioj žádají, co chtěji jíst, kde slabší člověk, obět' silného, krví a potem platí za své jho.

Radegasta Paroleka atdzejojums čehu valodā.

No grām.: Les duši: antologie lotyšské poezie 19. a 20. století ["Dvēsel̦u mežs. 19. un 20. gadsimta latviešu dzejas antolog̣ija”]. Sast. R. Paroleks, red. P. Štolls. Praha: Bohemika, 2001.

$* * *$

Nub' cigne blanka glitas tra la blu', kun ĝi mi volus flugi plu kaj plu al foroj, kie fremdas vintra proz', kie nur floras kaj ne velkas roz

Por kio, ho koro, la vana sopir'? Jam kuŝu l' esperoj en tomba mallumo: ne gvidas tra valoj sunplenaj la ir', vagadas la homo sur larma marĉhumo; 
martelas senĉese la fero kaj ŝtal', por pan', por nutrajo ne cesas batal', malforton kruele muelas la fort', ŝvit' fluas kaj sango, ĝis venas la mort'.

Nikolaja Kurzēna atdzejojums esperanto valodā.

No: Literatura Mondo, 1934, Nr. 8 [literārs žurnāls, Budapešta; numurs veltīts latviešu kultūrai].

Pieejams arī: http://www.esperanto.es:8080/xmlui/bitstream/handle/11013/ 1474/LM\%201934-08c.pdf?sequence $=1$ \&isAllowed $=\mathrm{y}$ [sk. 23.05.2020.]

$* * *$

Kui valged luiged taevas pilvelend, Küll nendega ma kaasa pakuks end, Seal kaugel maal ei keegi talve tea, Ja roosid seal närbuma ei pea.

Miks, süda, sa asjata unistad veel, Aeg päikesevalusad lootused tappa, Peab surelik kõndima pimedal teel, Kus unelmad ujuvad silmavee rappa. Kus kirved on kajamas, ragiseb raud, Kus leiba ja vett hüüab orjade laud, Kus jõulisem murda võib nõrkade väed, Kus higi ja verd aina voolamas näed.

Matsa Trāta atdzejojums igauṇu valodā.

No: Edasi, 1967, 8. okt. [dienas laikraksts, iznāk Tartu].

Pieejams arī: https://eduardsveidenbaumsblog.wordpress.com [sk. 23.05.2020.]

$* * *$

Kui luiged valged pilved mööduvad

Ah saaksid vaid mu kaasa viia nad

Nii kaugele, kus talve polegi

Kus jäävalt õitseb roos - ei koolegi

Miks asjata lootust küll tulvil on rind

Kord lootuskiir mädaneb maapõues tülkas

Ei päikesemaa oota, surelik, sind

Pead elama pisaraist vettinud mülkas

Kus ahelakolin ja kirveste kulg

Ei vaibu - ja näljaste orjade ulg,

Kus toores jõud üle käib nõrgema tõest,

Verd, higi kus voolab kõik päevad kui jõest. 
Contras atdzejojums igauṇu valodā.

No: Veidenbaums, E. Mind ärge lugege ["Mani nelasiet"]. Sast. Contra. Pärnu, Jumalikud Ilmutused, 2014.

Pieejams arī: https://eduardsveidenbaumsblog.wordpress.com [sk. 24.05.2020.]

\section{LYG GULBE்S}

Balti, lyg gulbès, debesèliai plaukia, Mane vilioja, plaukti sykiu traukia

Tenai, toli, žiemos kur nepažįsta, Kur rožès žydi, amžių nenuvysta.

Širdie, kam bergždžiai dar tu laimès besieki?

Viltis ị kapyno mesk tamsujj urvą:

Numiršti - saulètą pasaulị palieki, O gyvas turi tiktai ašarų purvą.

Balti, lyg gulbès, debesèliai plaukia, Mane vilioja, plaukti sykiu traukia

Tenai, toli, žiemos kur nepažista, Kur rožès žydi, amžių nenuvysta.

Justa Paḷecka atdzejojums, precīzāk - parafrāze - lietuviešu valodā. Trešā strofa nav atdzejota, tās vietā atkārtota pirmā strofa.

No: Naujas Žodis [žurnāls, Kauna un Rīga]. 1925, Nr. 515, jūn.; t. p. arī: Paleckis, J. Dienų nelaisvèj ["Dienas gūstā”]: Eiléraščiai ir vertimai [Dzejoḷi un tulkojumi]. Kaunas, 1932, 48. lpp. [Kā oriǵināla autors kḷūdaini norādīts Kārlis Skalbe.]

\section{KAIP GULBĖS}

Kaip gulbès debesys baltučiai plaukia, Mane vilioja, plaukti sykiu traukia Tenai toli, žiemos kur nepažǐsta, Kur žydi rožès, amžiais nenuvysta.

Širdie, kam bergždžiai dar tu laimès besieki?

Viltis ị kapyno mesk tamsųji urvą:

Numiręs - saulètą pasauli palieka, O gyvas turi tiktai ašarų purvą, Kur geležys, kirviai nerimdami žvanga, Išalkę vergai duonos trupinius renka, Stipriųjų paminti kur lūžta silpnieji, Kasdien kur jie ašaras, prakaitą lieja.

Justa Paḷecka atdzejojums lietuviešu valodā. No: Pergale, 1960, Nr. 8 [literārs žurnāls, Viḷna]. 
$* * *$

Jakby łabędzi białość obłok rwie,

Niechże ten obłok biały weźmie mnie,

Niechże mnie niesie w dal, w ów kraj bez zim,

Gdzie róże niezwarzone wiatrem złym.

Prózno się serce, spalasz w ogniu żądz,

Nadziejom twoim tylko grobu ciemnia,

Śmiertelnik, będziesz wiecznie żył bez słońc,

W bagnisku, które mokry płacz zapełnia.

Tu siekier brzęk, żelazny dzwoni cep,

Tu niewolniczy ciągły krzyk o chleb,

Tu siła łamie głos dławionych ust,

Potu i krwi codzienny szemrze plusk.

Stanislava Čerṇika atdzejojums poḷu valodā.

No grām.: Antologia poezji łotewskiej ["Latviešu dzejas antoloğija"]. Sast.

L. Bērziņš, S. Kolbuševska komentāri. Ostrzeszow: B-ka okolicy poetow, 1938.

Pieejams arī: https://eduardsveidenbaumsblog.wordpress.com [sk. 24.05.2020.]

$* * *$

Mint hattyúk úsznak fehér fellegek,

Velük szállnék én is a táj felett

Oda messze, hol a tél ismeretlen,

És rózsák nyílnak, s nem hervad el egy sem -

Ó, szívem, az üdvöd hiába ne lesd,

Vesd sír fenekére az álmokat végre:

Halandót a fény hona bé nem ereszt,

Sivár ingoványon kell éltét leélje,

Hol lánc csörög szüntelen, s fejsze kopog,

$S$ létért, falatért rínak a rabok,

Hol a gyönge ledől, az erős ha ítélt,

És ömlik örökkön a vér s veríték.

Gābora Garai atdzejojums ungāru valodā.

No grām.: A lett irodalom kistükre ["Maza latviešu literatūras izlase"]. Sast.

I. Bērsons. Budapest, 1977.

Pieejams arī: https://eduardsveidenbaumsblog.wordpress.com [sk. 24.05.2020.]

$* * *$

So weiß wie Schwäne seh' ich Wolken ziehn -

mit ihnen möcht' ich in die Ferne fliehn,

dorthin, wo niemals Winterwinde wehn,

wo Rosen ewig blühn und nie vergehn ...

Was gierst du umsonst nach Glückseligkeit, Herz? 
Wirf endlich dein Hoffen ins Grab, in das dumpfe:

im Tale der Sterblichen waltet der Schmerz, kein Sonnenstrahl küßt sie im trän'feuchten Sumpfe, wo Äxte und Ketten ohn' Unterlaß kreischen, wo Sklaven nach Brot, nach dem täglichen, heischen, der Schwache vom Stärkren zertreten erlischt, und Schweiß sich mit Blut alle Tage vermischt.

Matiasa Knolla atdzejojums vācu valodā.

Iepriekš nepublicēts.

$* * *$

Как белые лебеди, тянется тучек семья.

Хотел бы я с ними в те милые сердцу края,

Где люди не знают суровой зимы и мороза,

Где вечно цветут благовонные юные розы...

О сердце! Навеки надежды свои схорони.

Не надо о счастье несбыточном праздных мечтаний.

Тебе отмежеваны в жизни болота одни, -

Страна нескончаемых слез и безумных страданий,

Где тюрьмы и пытки и виселиц черных столбы.

Где просят напрасно пощады и хлеба рабы,

Где сильные слабых терзают и топчут без счета,

Где льются безбрежные реки и крови, и пота...

Isaakija Mordvinova atdzejojums krievu valodā.

No: Север, 1908, № 50 [literārs žurnāls, Sanktpēterburga].

$* * *$

Как белый лебедь, облако плывет, Уплыть и мне б за облаком вперед, В далекий край, где зимы не гнетут,

Где вечно розы алые цветут.

Зачем, сердце, рвешься ты в край вечных роз?

Нет, смертный попасть, в этот край не сумеет, -

И жить ему в липкой трясине слез, ${ }^{12}$

В краю, где надежды в могиле истлеют,

Где скрежет немолчный и звон кандалов,

Где слышатся стоны голодных рабов,

12 Pēc 1953. gada šīs divas rindas: Нет, смертных там солнца лучи не согреют / - И жить им в трясине печали и слез. 
Где слабого сильный жестоко гнетет, Где потом и кровью исходит народ.

Grigorija Gorska atdzejojums krievu valodā.

No grām.: Вейденбаум, Э. Избранное [“Izlase”]. A. Upīša priekšv., G. Gorska tulk., J. Abizova red. Рига: Латгосиздат, 1953.

Pieejams arī: https://eduardsveidenbaumsblog.wordpress.com [sk. 24.05.2020.]

$* * *$

За лебединой стаей облаков

И я пустится в дальний край готов,

Где так тепло, где вовсе нет зимы,

Где розы круглый год срывали б мы.

O, сердце, расстанься с мечтами навек!

Напрасно ты носишься с ними доныне:

Не в райских долинах живет человек,

Пред ним безысходного горя трясины,

Где лязг топора, где оковы стучат,

Где толпы рабов лишь о хлебе кричат,

Где правда пред силой сгибаться должна,

Где потом и кровью земля вспоена.

Vladimira Bugajevska atdzejojums krievu valodā.

No grām.: Антология латышской поэзии ["Latviešu dzejas antologijija"]. Sast. J. Sudrabkalns, A. Grigulis, M. Ķеmpe. Рига: Латгосиздат, 1955.

$* * *$

За лебединой стаей облаков

Туда умчаться я мечтой готов,

Где не бушуют зимы снежные,

Где вечно свежи розы нежные...

О счастье несбыточном, сердце, забудь

И брось наконец все надежды в могилу:

Заказан в края эти смертному путь,

Он жить обречён среди топи постылой,

Где люди в труде наживают горбы,

Где хлеба голодные просят рабы,

Где слабого сильный топчет, гнетёт,

Где льются обильно и слезы и пот.

Igora Grigorjeva atdzejojums krievu valodā.

No grām.: Антология латышской поэзии в двух томах ["Latviešu dzejas antoloǵija divos sējumos]. 1. sēj. Москва; Ленинград: Художественная литература, 1959. 
$* * *$

Как лебеди, скользя в голубизне, Проходят облака, уйти б и мне

За ними вдаль, туда, где стужи нет, Где вечен роз благоуханный цвет.

Зачем же ты счастья, душа моя, ждешь?

В могиле сырой схорони свои грезы, Ты, смертная, светлых долин не найдешь, Их нет на земле, твой удел там, где слезы, Где скрежет железа и стук топоров, Где стоны от голода мрущих рабов,В трясине из слез тебе жить довелось, Пропитанной потом и кровью насквозь.

Leonīda Čerevičnika atdzejojums krievu valodā.

No grām.: Вейденбаум, Э. Стихотворения [“Dzejas”]. J. Rokpeḷn, priekšv. Рига: Лиесма, 1980.

Pieejams arī: https://eduardsveidenbaumsblog.wordpress.com [sk. 24.05.2020.]

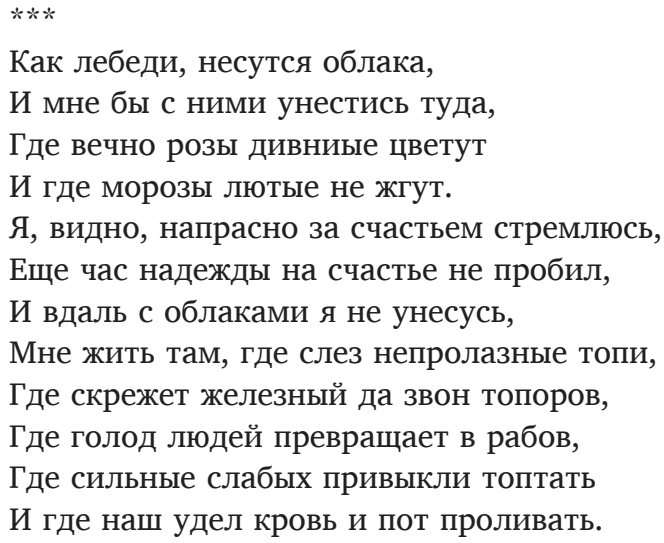

Fēliksa Kaca tulkojums krievu valodā.

No: Будни [Latvijas krievu laikraksts], 1998, 15/21 янв, с. 16.

$* * *$

Мов білі лебеді, пливуть хмарок гурти.

Як слідом я б хотів за ними поплисти.

у мрійну далину, де не бува зими,

Де, мов троянди ті, змогли б цвісти і ми. 
Hi, серце, рвешся ти, повір мені, дарма,

Жени надії геть! Не збутись їм довіку

В країні, де в людей ніяких прав нема,

Де стільки сліз навкруг, що розлилися ріки,

Де в праці зрання й допізна раби

За хліба крихту гнуть свої горби,

Де кожний на собі відчути може світ

Де тільки ллеться кров,

Де тільки ллеться піт.

Kosta Overčenko atdzejojums ukraiņu valodā.

No grām.: Латвія поетична: Поети Латвї в українському перекладі Костя Оверченка ["Poētiskā Latvija: Latvijas dzejniekus ukrainiski tulkojis Kosta Overčenko”]. K. Skujenieka priekšv. Рига: DIAC, 2007.

\section{Eduarda Veidenbauma dzejoḷu atdzejojumi citās valodās}

Turpmāk kvadrātiekavās norādīti Veidenbauma dzejoḷu nosaukumi, savukārt pēdin̄ās - dzejoḷu kopu un krājumu nosaukumu tulkojumi. Ja atdzejojumu skaits ir lielāks nekā astoṇi dzejoḷi, tad to nosaukumi vairs nav norādīti, visu korpusu aizstājot ar norādi [Dzejoḷu kopa]. Vākums veidots latviešu lasītājam, oriǵninālā atstājot tikai pašu nepieciešamāko informāciju, arī tai pēc iespējas pievienojot tulkojumu.

\section{Ang!̣ valodā}

Krājumos:

Veidenbaums, E. Mist-waves and darkness... [Tumsa un migla pasauli sedz...]. Grām.: The Tricolour Sun. Latvian Lyrics in English Version. ["Trejkrāsainā saule. Latviešu lirika angliskā versijā”]. Sast., atdzej. V. K. Metjūss. Cambridge: Heffer, 1936, 25. lpp.

Veidenbaums, E. Mist-waves and darkness... [Tumsa un migla pasauli sedz...]. Grām.: A Century of Latvian Poetry. An Anthology ["Latviešu dzejas gadsimts. Antoloǵija”]. Sast., atdzej. V. K. Metjūss. London: John Calder, 1957, 33. lpp.

\section{Baltkrievu valodā:}

Periodika:

Вейдэнбаумы, Э. А прауды на свеце нямя! Гэта ж смех... [Virs zemes nav taisnības...]; Пасаду хочашь мець 3 выгодных... [Ja gribi tikt pie labas vietas...]; Былыя грахі шкадавания не варты... [Par velti ir nožēlot agrākos grēkus...] / atdzej. A. Bačila. Лimapamypa i мастац̨вва [baltkrievu iknedēḷas kultūras laikraksts], 1967, 3 кастр. (okt.), № 78. 


\section{Esperanto}

Periodika:

Veidenbaums, E. Nub' cigne blanka... [Kā gulbji balti padebeši iet...] / atdzej. N. Kurzēns. Literatura Mondo, 1934, Nr. 8 [literārs žurnāls, Budapešta]. Pieejams arī: http://www.esperanto.es:8080/xmlui/bitstream/handle/11013/ 1474/LM\%201934-08c.pdf?sequence = 1\&isAllowed = y [sk. 23.05.2020.]

Veidenbaums, E. Nub' cigne blanka... [Kā gulbji balti padebeši iet...] / atdzej. N. Kurzēns. Zvaigzne, 1958, Nr. 10, 32. lpp.

\section{Franču valodā}

Krājums:

Veidenbaums, E. Les générations disparaissent du monde comme des rêves... [Kā sapñi no pasaules dzimumi zūd...] / atdzej. E. Stērste. Grām: Poèmes lettons ["Latviešu dzeja"]. P. Azāra priekšvārds, E. Virzas ievads. Rīga: Edité par la Section de la presse au ministère des affaires étrangères de Lettonie 1931, 24. lpp.

\section{Igauṇu valodā}

\section{Periodika:}

Veidenbaums, E. Käin kuulamas kui lõppend päevatöö... [Kur klusā naktī lakstīgalas dzied...], Kui valged luiged taevas pilvelend... [Kā gulbji balti padebeši iet...], Sa mäleta piinatud vendi... [Tu atmini cietējus brāḷs...] / atdzej. M. Trāts, L. Kamara. Edasi [Tartu], 1967, 8. okt.

Veidenbaums, E. Ärka, ärka kord vabana, vaim... [Mosties, mosties reiz, svabadais gars..] / atdzej. M. Trāts un L. Kamara. Edasi [Tartu], 1967, 15. okt., Nr. 244.

Veidenbaums, E. Kui tahad saada hästi läbi... [Ja gribi tikt pie labas vietas...] / atdzej. A. Kāleps. Sirp ja Vasar [Tallinas nedēḷas avīze], 1967, Nr. 40.

Krājums:

Veidenbaums, E. Mind ärge lugege ["Mani nelasiet”]. Atdzej. Contra. Pärnu: Jumalikud Ilmutused, 2014.

Interneta resurss:

https://eduardsveidenbaumsblog.wordpress.com [sk. 24.05.2020.]

\section{Krievu valodā:}

Periodika:

Вейденбаумъ, Э. И дождь над грязью улиц, и ветра вой гудит... [“Pa ielām dubḷainām līst lietus...”] / atdzej. S. Šervinskis; Изъ мира, словно сонъ, уходятъ поколъния... [No pasaules kā sapnis, aiziet paaudzes... - dzej. "Kā sapņi no pasaules dzimumi zūd..."] / atdzej. J. Sireiščikova; Всё мутно от лунного света... [Viss miglains mēness gaismā... - dzej. "Pie debesīm 
mēness spīd bālais..."]; ar virsrakstu Поэту [Dzejniekam] - dzejolis "Kam velti dārgo laiku tērē..." (К какому ты стремишься благу... [Pе̄c kāda labuma tu dzenies...]), Где журчит в тени у ската... [Kur ēnā burbuḷo pie nogāzes...] - dzej. "Upes malu liepas ēno...”] / atdzej. Е. Virza. Рижский курьер, 1924, 24 фев. Pieejams arī: https://rigastar.jimdo.com [sk. 24.05.2020.]

Вейденбаумъ, Э. Весна. Весною повеяло в поле... [Рār laukiem jau ziedonis dvašo...] / atdzej. V. Tretjakovs. Сегодня, 1930, № 301, 31 окт.

Вейденбаумъ, Э. Уже друзья иные в хладном сне... [Jau vēsajās smiltīs dārgajie draugi dus...] / atdzej. V. Tretjakovs. Газета для всех, 1938, № 47, 20 ноября.

Вейденбаумъ, Э. В мае. Украсилось поле цвътами... [Jau ziediem rotātas pḷvas...] / atdzej. A. Formakovs. Сегодня, 1939, № 142, 23 мая.

Вейденбаум, Э. И дождь над грязью улиц... ["Ра ielām dubḷainām līst lietus..."] / atdzej. S. Šervinskis; Нет правды на земле... [Virs zemes nav taisnības...] / atdzej. J. Sireiščikova; Проснись, проснись, свободный дух... [Mosties, mosties reiz, svabadais gars!] / atdzej. J. Sireiščikova. Я помню счастливые годы... [Es atminos rožainos laikus...] / atdzej. J. Sireiščikova. Советская Латвия, 1945, 15 окт.

Вейденбаум, Э. Как белый лебедь, облако плывет... [Kā gulbji balti padebeši iet...]; Встань, воспрянь же, свободный дух... [Mosties, mosties reiz svabadais gars...] / atdzej. G. Gorskis. Советская Латвия, 1957, 24 мая.

Вейденбаум, Э. Дух свободы, воспрянь, проснись наконец... [Mosties, mosties reiz svabadais gars...]; За лебединой стаей облаков... [Kā gulbji balti padebeši iet...] / atdzej. I. Grigorjevs. Советская Латвия, 1967, 1 окт.

Вейденбаум, Э. За лебединой стаей облаков... [Ка̄ gulbji balti padebeši iet...] / atdzej. V. Bugajevskis. Рuгас Балсс, 1967, 3 окт, № 232.

Вейденбаум, Э. За лебединой стаей облаков... [Ка̄ gulbji balti padebeši iet...] / atdzej. V. Bugajevskis. Советская молодежь, 1967, 3 окт.

Вейденбаум, Э. О народ мой солнечный латышский... [“Tauta, tauta, gaišā latvju tauta..."] / atdzej. D. Brodskis, V. Šefners, G. Gorskis, V. Bugajevskis. Советская молодежь, 1967, 3 окт.

Вейденбаум, Э. Дух свободы, воспрянь... [“Mosties, mosties reiz, svabadais gars...”] / atdzej. В. Aleksejevs. ${ }^{13}$ Даугава, 1977, № 5, 79. lpp.

Вейденбаум, Э. Стихи [“Dzejas”] / atdzej. L. Čerevičniks. Даугава, 1978, № 11, 88.-93. lpp.

Вейденбаум, Э. Стихотворения [“Dzejolii”] / atdzej. L. Čerevičniks. Даугава, 1979, № 11, 78.-83. lpp.

Вейденбаум, Э. Стихотворения [“Dzejolii”] / atdzej. L. Čerevičniks. Даугава, 1980, № 8, 72.-76. lpp.

Вейденбаум, Э. Если доверчив сердцем живешь... [Ja tev pasaulē jūtīga sirds...] / atdzej. L. Čerevičņiks. Jaunās Grāmatas, 1981, Nr. 4, 17. lpp.

${ }^{13}$ Atdzejotāja vārda iniciālis, iespējams, ir kḷūdains. Tas varētu būt Vladimirs Aleksejevs, tātad vajadzētu būt V. Aleksejevs, nevis B. Aleksejevs (sk.: https://www.russkije.lv/ru/ pub/read/ezit-daugava/daugava_avtori1.html) 
Вейденбаум, Э. Ты властвовать мог бы здесь с сильными мира сего... [Ar šās zemes vareniem kopā tu varēji būt...], Я помню прекрасную пору... [Es atminos rožainos laikus...] / atdzej. L. Čerevičniks [atdzejotājs tekstā nav norādìts]. Заря коммунизма, 1987, № 110, 12 сен.

Вейденбаум, Э. Дух свободы, проснись, восстань... [Mosties, mosties reiz, svabadais gars!] / atdzej. L. Čerevičñiks. Даугава, 1987, № 11, 3. lpp.

Вейденбаум, Э. Как лебеди, скользя в голубизне... [“Kā gulbji balti padebeši iet...”] / atdzej. L. Čerevičniks. Родник, 1988, № 2, 25.-27. lpp.

Вейденбаум, Э. Цвет зелени... [Reiz zaloja jaunība...] / atdzej. L. Čerevičniks [atdzejotājs tekstā nav norādīts]. Советская молодежь, 1989, 1 мая.

Вейденбаум, Э. Есть множество честных людей, терпеливо... [Daudz prātīgu cilvēku pasaulē dzīvo...] / atdzej. L. Čerevičniks. Родник, 1989, № 9, 70.-71. lpp.

Вейденбаум, Э. Весною повеяло в поле... [Pār laukiem jau ziedonis dvašo...] / atdzej. V. Tretjakovs. Даугава, 1992, № 1, 88. lpp.

Вейденбаум, Э. Стихотворения [“Dzejolii”] / atdzej. L. Čerevičniks. Даугава, 1994, № 5 (septembris/oktobris), 75.-80. lpp.

Вейденбаум, Э. Словно голый средь крапивы... [Kuḷos es kā pliks pa nātrām...] / atdzej. G. Gorskis [atdzejotājs tekstā nav uzrādīts]; Богатство свое ты усердно копил... [Ikkatris tev godu dod, centīgais vīrs...] / atdzej. G. Gorskis, Коль жаждешь должности завидной... [Ja gribi tikt pie labas vietas...] / atdzej. G. Gorskis [atdzejotājs tekstā nav norādīts]. Лана, 1994, № 20, июл., 2. 1pp.

Вейденбаум, Э. Ты вспомни о страждущих братьях... [Tu atmini cietējus brāḷus...] / atdzej. F. Касs. Будни, 1997, 18/24 дек., 8. lpp.

Вейденбаум, Э. Новый год уже пришел, но жизнь людская... [Jauns gads jau atnācis...]; Как лебеди, несутся облака... [Kā gulbji balti padebeši iet...] / atdzej. F. Касs. Будни, 1998, 15/21 янв., 16. lpp.

Вейденбаум, Э. В жизни чти одну монету... [Ej un dzenies tik pēc naudas...] / atdzej. G. Gorskis [atdzejotājs tekstā nav norādīts]. Утренний экспресс, 1999, 16 апр.

Krājumi:

Вейденбаум, Э. Избранное [“Izlase"] / atdzej. G. Gorskis, J. Abizova red., A. Upīša ievads. Рига: Латгосиздат, 1953.

Вейденбаум, Э. Стихотворения [“Dzejolıi”] / atdzej. G. Gorskis, J. Sudrabkalna ievads. Москва: Государственное издательство художественной литературы, 1961.

Вейденбаум, Э. Стихотворения [“Dzejoḷi”] / atdzej. L. Čerevičñiks. Рига: Лиесма, 1980.

Antologijas:

Вейденбаум, Э. Когда я молодъ былъ... [Reiz zalıja jaunība, cerības plauka...] / atdzej. J. Sireiščikova; Изъ мира, словно сонъ, уходятъ покольния... [Kā sapņi no pasaules dzimumi zūd ...] / atdzej. J. Sireiščikova; Нъть правды на землъ... [Virs zemes nav taisnības...] / atdzej. J. Sireiščikova; 
И дождь надъ грязью улицъ... [Pa ielām dublainām līst lietus...] / atdzej. S. Šervinskis; Я помню счастливые годы... [Es atminos rožainos laikus...] / atdzej. J. Sireiščikova; Проснись, проснись, свободный духъ... [Mosties, mosties reiz, svabadais gars!] / atdzej. J. Sireiščikova]. Grām.: Сборник латышской литературы [“Latviešu literatūras krājums"]. Red. V. Brjusovs, M. Gorkijs. Петроград: Парус, 1916, 124.-126. lpp.

Вейденбаум, Э. Весною повеяло в поле... [Pār laukiem jau ziedonis dvašo...]; Уже друзья иные в хладном сне... [Jau vēsajās smiltīs dārgajie draugi dus...]; На улицах дождливо, там грязь и ветра вой [Pa ielām dublainām līst lietus...] / atdzej. V. Tretjakovs. Grām.: Латышские поэты [“Latviešu dzejnieki”]. Рига: Вальтер и Рапа, 1931, 9.-11. lpp.

Вейденбаум, Э. Стихи [“Dzeja”] / atdzej. G. Gorskis. Советская Латвия: литературно-художественный альманах Союза Советских писателей Латвии. [Рига]: 1952. 3. sēj. 176.-185. lpp.

Вейденбаум, Э. [Dzejolu kopa] / atdzej. V. Bugajevskis, G. Gorskis, V. Nevskis, D. Brodskis, V. Šefners. Grām.: Антология латышской поэзии ["Latviešu dzejas antoloǵija”]. Sast. J. Sudrabkalns, A. Grigulis, M. Kempe. Рига: Латгосиздат, 1955, 109.-118. lpp.

Вейденбаум, Э. [Dzejoḷu kopa] / atdzej. В. Aleksejevs, ${ }^{14}$ I. Grigorjevs, V. Šefners, V. N̦evskis, V. Tretjakovs. Grām.: Антология латышской поэзии в двух томах ["Latviešu dzejas antologija divos sējumos"]. Sast. A. Vējāns, V. Rūja. 1. sēj. Москва; Ленинград: Художественная литература, 1959. 109.-117. lpp.

Вейденбаум, Э. Божья милость [Dievs ir laipnīgs: mācītājus]. Grām.: Маршак С. Собрание сочинений в 8 томах ["Kopoti raksti 8 sējumos"]. 4. sēj. Переводы: Из народной поэзии. Эпиграммы. Из зарубежных поэтов. Из поэтов народов СССР [“Tulkojumi. Tautas dzejas. Epigrammas. Ārvalstu dzejnieki. PSRS tautu dzejnieki”]. Москва: Художественная литература, 1969. 543. 1pp.

Вейденбаум, Э. О, как меня всегда края влекут... [Kur klusā naktī lakstīgalas dzied...]; Мне надоели розы, надоело...[Ра rožu ziediem mājās rotājoties...] / atdzej. G. Gorskis. Grām.: Песнь любви. Любовная лирика народов СССР ["Mīlas dziesma. PSRS tautu mīlas lirika"]. 2. sēj. Sast. S. Magidsone, red. L. Ozerovs. Москва: Молодая гвардия, 1972, 677. lpp. Вейденбаум, Э. Нет правды на свете! Богач - выше всех... [Virs zemes nav taisnības] / atdzej. V. N̦evskis; За лебединой стаей облаков... [Kā gulbji balti padebeši iet...] / atdzej. I. Grigorjevs; Дух свободы, воспрянь, проснись наконец... [Mosties, mosties reiz, svabadais gars!] / atdzej. B. Aleksejevs. Grām.: Латышская литература. Книга для чтения в V-VIII классах с русским языком обучения ["Latviešu literatūra. Lasāmgrāmata 5.-8. klasei skolās ar krievu mācību valodu"]. Sast. В. Infantjevs. Рига: Звайгзне, 1973, 145.-146. lpp.

${ }^{14}$ Sk. 13. zemsvītras norādi. 
Вейденбаум, Э. [Dzejoḷu kopa] / atdzej. G. Gorskis. Grām.: Поэть Латвии [“Latvijas dzejnieki”]. Sast. I. Ziedonis, red., V. Roždestvenskis, V. Valeiṇa ievads. Ленинград: Советский писатель. Ленинградское отделение, 1974, 95.-104. 1pp.

Вейденбаум, Э. О, как меня всегда края влекут... [Kur klusā naktī lakstīgalas dzied...]; Встань, воспрянь же, свободый дух!... [Mosties, mosties reiz, svabadais gars!...]; Словно голый средь крапивы... [Kuḷos es kā pliks pa nātrām...]; Друг, на всей земле свободы... [Draugs, uz visas zemeslodes...]; То я знаю, то смогу я... [To es zinu, to es māku...]; Богатство свое ты усердно копил... [Ikkatrs tev godu dod, centīgais vīrs...]; Кто по лугам среди цветов гуляет... [Kas, staigājot pa košām puk,u lejām...]; Люди несчастные... [Vienkārši l,autiṇi...] / atdzej. G. Gorskis. Grām.: Поэзия народов СССР XIX - начала XX века ["PSRS tautu dzeja 19. gadsimtā un 20. gadsimta sākumā”]. Sast. L.. Arutjunovs. Москва: Художественная литература, 1977, 182.-185. lpp.

Вейденбаум, Э. По нивам латышским и долам... [Рa Latvijas kalniem un lejām...]; Мир звонкою песней взволнован... [Jau ziediem rotātas pḷavas...]; Нет правды на свете, царит лишь кулак... [Virs zemes nav taisnības, dūrei tik spēks...]; О народ, народ латышский светлый... [Tauta, tauta, gaišā latvju tauta...] / atdzej. G. Gorskis. Grām.: Роднъе нивы: Поэзия XIX начала XX века ["Dzimtās druvas: 19. un 20. gadsimta sākuma dzeja”]. Sast. N. Bannikovs. Москва: Художественная литература, 1984, 353.-354. lpp.

Вейденбаум, Э. [Dzejol,u kopa] / atdzej. G. Gorskis. Grām.: В вечном созвучии: Сборник стихов русских и латыцских поэтов ["Mūžīgā saskan̄ā: latviešu un krievu liriḳu dzejoḷu krājums”]. Sast. L. Osipova. Москва: Современник, 1985, 42.-44. 1pp.

Вейденбаум, Э. [Dzejol,u kopa]. Grām.: Пути огня: из латышской классической поэзии [“Uguns cel̦i: No latviešu dzejas klasikas"]. Sast., tulk. un komentāru autors L. Čerevičniks. Рига: Лиесма, 1986, 9.-49. lpp.

Вейденбаум, Э. Встань, воспрянь же, свободый дух... [Mosties, mosties reiz, svabadais gars...] / atdzej. G. Gorskis; Как белый лебедь, облако плывет... [Kā gulbji balti padebeši iet...] / atdzej. G. Gorskis; Средь розовых кустов, над мирным кровом... [Ра rožu ziediem mājās rotājoties] / atdzej. V. Šefners; Не стоят былые грехи сожаленья... [Par velti ir nožēlot agrākos grēkus...] / atdzej. V. Šefners]; Нет правды на свете! Богач выше всех... [Virs zemes nav taisnības! Dūrei tik spēks...] / atdzej. V. N̦evskis. Grām.: Стихи поэтов народов дореволюционной России (XIX - начало $X X$ в.) ["Krievijas pirmsrevolūcijas tautu dzejnieku lirika (19. gs. - 20. gs. sākums)"]. Sast. un komentāru autore N. Kuprijanova, V. Aleksandrova priekšvārds. Москва: Детская литература, 1987, 451.-453. lpp.

Вейденбаум Э. [Dzejoḷu kopa]. Tulk. L. Čerevičniks. Grām.: На вешних ветрах: Латьшиская классическая поэзия ["Pavasara vējos: latviešu dzejas klasika"]. Sast., tulk. un ievada autors I. Auziņš. Москва: Художественная литература, 1988, 35.-53. 1pp. 


\section{Lietuviešu valodā}

Periodika, krājumi:

Veidenbaumas, E. Lyg gulbès... [Kā gulbji balti padebeši iet...] / atdzej. J. Paḷeckis. Naujas Žodis [žurnāls], Kauṇa un Rīga, 1925, Nr. 5, 15. jūn.

Veidenbaumas, E. Lyg gulbès... [Kā gulbji balti padebeši iet...]. Grām.: Paleckis, J. Dienu nelaisvèj ["Dienas gūstā”]. Eiléraščiai ir vertimai [Dzejoḷi un tulkojumi]. 2. izd. Kaunas, 1932. 48. lpp.

Veidenbaumas, E. Kaip gulbès... [Kā gulbji balti padebeši iet...]; Atminki [Tu atmini cietējus brāḷus...]; Nèr žemèj teisybès... [Virs zemes nav taisnības, dūrei tik spēks...]; Žmonių padorių daug pasauly gyvena... [Daudz godīgu cilvēku pasaulē dzīvo...]; Lyg po dilgèles kuliuosi... [Kuḷos es kā pliks pa nātrām...]; Sunkių laikų neboja... [Par spīti grūtiem laikiem...]; Kur skamba naktimis lakštingalų daina... [Kur klusā naktī lakstīgalas dzied...]; Kelkis pabudusi laisvès dvasia... [Mosties, mosties reiz, svabadais gars...] / atdzej. J. Paleckis. Pergale, 1960, Nr. 8, 115.-117. lpp.

Veidenbaumas, E. Kaip gulbės... [Kā gulbji balti padebeši iet...]; Kelkis pabudusi laisvès dvasia... [Mosties, mosties reiz, svabadais gars...]; Nèr žemèj teisybės... [Virs zemes nav taisnības, dūrei tik spēks...]; Kur skamba naktimis lakštingalų daina... [Kur klusā naktī lakstīgalas dzied...]; Atminki [Tu atmini cietējus brālus...] / atdzej. J. Paḷeckis. Grām.: Paleckis, J. Gyvenimo vardu ["Dzīves vārdā"]. Vilnius: GVLL, 1961. 91.-96. lpp.

Veidenbaumas, E. Kelkis, pabuski, laisvès dvasia... [Mosties, mosties reiz, svabadais gars...], tulk. J. Pal,eckis; Kam veltui gaišti brangų laiką? [Kam velti dārgo laiku tērē...], Tarp rožių krūmų, po skliautu taikiuoju... [Pa rožu ziediem mājās rotājoties...] / atdzej. E. Matuzēvičs. Literatūra ir menas, 1967, 30. sept.

Veidenbaumas, E. Galvą slegia mintys gilios... [Domāju es domas dziḷas...] / atdzej. J. Pal̦eckis. Grām.: Paleckis, J. Tūkstantis žingsnelių [“Tūkstoš soḷu”]. Vilnius: Vaga, 1970. 133.-135. lpp.

Veidenbaumas, E. Galvą slegia mintys gilios... [Domāju es domas dziḷas...] / atdzej. J. Paḷeckis. Grām.: Paleckis, J. Žurnalisto kelio atšvaitai: publicistika, eilèraščiai ir vertimai ["Žurnālista ceḷa atspulgi: publicistika, dzeja, tulkojumi”]. Sast. M. Juodaitīte. Vilnius: Žuvèdra, 2017, 328.-330. lpp.

\section{Interneta resurss:}

Veidenbaums, E. Išgerk bruoli! Eikliom kojom... [Iedzer, brāli! Vieglām kājām...] / atdzej. V. Butkus. Pieejams: https://www.facebook.com/photo.php? fbid $=2897534940275964 \&$ set $=$ a. 109517342411085\&type $=3 \&$ theater [sk. 01.09.2019.]

\section{Poḷu valodā}

\section{Krājumā:}

Veidenbaums, E. Moźna rozwaźać bez końca, po co jest źycie czlowieka... [Daudz varam runāt un spriest...]; Ma byc wojna, - z Niemcem czy Moskalem... [Vai karš būs ar vāciešiem, krieviem...]; Jakby łabędzi białość obłok rwie... 
[Kā gulbji balti padebeši iet...]; Odrzucę wreszcie nab ok czarne smutki... [Nost reiz skumību metīšu tumšo...]; Kwiatami błyszczą tak trawy... [Jau ziediem rotātas pḷavas...] / atdzej. S. Čerṇiks. Grām.: Antologia poezji łotewskiej ["Latviešu dzejas antolog̣ija”]. Sast. L. Bērziņš, S. Kolbuševska komentāri. Ostrzeszow: B-ka okolicy poetow, 1938, 26.-30. lpp.

\section{Ukraiṇu valodā:}

Periodika:

Вейденбаум, Е. Серед барвистих квіtів никать на полях... [Рa rožu ziediem mājās rotājoties...]; Братів не забудь, що в неволі... [Tu atmini cietējus brāḷus...]; Якщо серце усе відчува... [Ja tev pasaulē jūtīga sirds...]; На зло часу лихому... [Par spīti grūtiem laikiem...]; Піднятись на Олімп нам не дано в наш час... [Nākt Olimpā mums aizliedz dievu spēks...] / atdzej. К. Overčenko. Літературна Украіна, 19673 жовт. (okt.), № 39.

Antologija:

Вейденбаум, Е. [Dzejol,u kopa] / atdzej. K. Overčenko. Grām.: Латвія поетична: Поети Латвї̈ в украӥнському перекладі Костя Оверченка [“Poētiskā Latvija: Latvijas dzejniekus ukrainiski tulkojis Kosta Overčenko”]. Sast. G. Jurčonoka, K. Skujenieka priekšv. Рига: DIAC 2007, 92.-102. lpp.

\section{Ungāru valodā}

Antologijīa:

Veidenbaums, E. Mint hattyúk úsznak fehér fellegek... [Kā gulbji balti padebeši iet...] / atdzej. G. Garai; Mélabúsan eltûnődtem... [Domāju es domas dziḷas...] / atdzej. T. Deže; Sok jóravaló kéz akad e világon... [Daudz godīgu cilvēku pasaulē dzīvo...] / atdzej. T. Deže; Nincs földi igazság más, csak ököljog... [Virs zemes nav taisnības...] / atdzej. T. Deže; Ébredj, szabadságnak szelleme, kelj... [Mosties, mosties reiz, svabadais gars...] / atdzej. T. Deže. Grām.: A lett irodalom kistükre ["Maza latviešu literatūras izlase”]. Sast. I. Bērsons. Budapest, 1977, 137.-141. lpp. Pieejams arī: https:// eduardsveidenbaumsblog.wordpress.com [sk. 24.05.2020.]

\section{Vācu valodā}

Antologija:

Veidenbaums, E. Wo traulich nachts die Nachtigallen flöten... [Kur klusā naktī lakstīgalas dzied...], Gedenke der darbenden Brüder... [Tu atmini cietējus brāḷus...], Mühsam sich durchs Leben ringen... [Kuḷos es kā pliks pa nātrām...], Nach Ehre, nach Macht, nach Vermögen... [Pēc goda, pēc varas, pēc mantas...]. Grām.: Wunder und Wunden. Lyrik aus Lettland. Zweisprachige Anthologie. ["Brīnumi un ievainojumi. Dzeja no Latvijas. Bilingvāla antologija”]. Atzej. M. Knolls. Köln: Mare Balticum, 1993. 
Nošu izdevums:

Veidenbaum, E. Seht, wie die Kerzen leuchtend brennen... [Raug, svētku eglìte tik koši, tik mīlīgi, tik gaiši spīd...] / atdzej. K. Fr. Kohs. Grām.: Sanders, V. Ziemassvētku dziesma [notis] = Weihnachtslied / Wiswald Sanders; Ed. Veidenbaum, [vārdi]. [B. v.]

\section{Appendix Veidenbaums's poetry rendered in translations. Selection}

\section{Māra Grudule, Marians Rižijs}

According to the available sources, poems by Eduards Veidenbaums have been translated by 34 translators in twelve languages: English, Byelorussian, Czech, Esperanto, French, Estonian, Russian, Lithuanian, Polish, Ukrainian, Hungarian and German.

Primarily, Eduards Veidenbaums's poetry has been translated into Russian. The first translation entitled В болотах (In the Marshes) of his well-known poem Kã gulbji balti padebeši iet (White clouds are passing like swans) was made as early as 1907 and published a year later in St. Petersburg, in the Russian weekly periodical "Север". ${ }^{15}$ The translator Isaaky Mordvinov (Исаакий Мордвинов) was a Russian language teacher and one of the organizers of the 1905 strikes in Valka, a town situated in the northern part of Latvia, near the Estonian border.

The popularity of Veidenbaums's poems in Russian was determined by close ties between Latvian modernists and the most outstanding representatives of Russian Symbolism at the beginning of the $20^{\text {th }}$ century. Mutual interest and cooperation was confirmed by the anthology of Latvian poetry Сборник латышской литературы (Anthology of Latvian Literature, 1916). ${ }^{16}$ In this anthology, Veidenbaums's poetry following the interlinear translation in Russian was compiled by Yelena Sireiscikova (Елена Сырейщикова) and Sergey Shervinsky (Сергей Шервинский). The entire collection was edited by a well-known Russian writer symbolist Valery Bryusov (Валерий Брюсов). The translations of Sireiscikova and Shervinsky were also published later in Russian periodicals of the interwar period in Latvia and immediately after World War II. In the first half of the 1920s, Veidenbaums's poetry was translated into Russian by the outstanding Latvian poet Edvarts Virza. In the 1930s, three poems were translated by the journalist and poet Viktor Tretyakov (Виктор Третьяков), one of the former members of the Russian modernist group Цех поэтов (Poets' Factory) as well as the translator of the English poet William Wordsworth's works. Due to the Russian Revolution and the ensuing Civil War, Tretyakov

15 1908, № 50, с. 758.

16 Сборник латышской литературы. Петроград: Парус, 1916, с. 124-126. 
emigrated to Latvia in 1921 after graduating from the Russian Academy of Arts. Tretjakov's translations of Veidenbaums's poetry were published both in local Russian periodicals and in the anthology of Latvian poetry in Russian, compiled and translated by himself. ${ }^{17}$

During the interwar period, the first translations of Veidenbaums's poetry in English, ${ }^{18}$ French, ${ }^{19}$ German, ${ }^{20}$ Polish, ${ }^{21}$ as well as Lithuanian ${ }^{22}$ and Esperanto ${ }^{23}$ were published. Nature and existential motifs dominated in these translations.

After World War II, the inclusion of Veidenbaums in the canon of Sovietaccepted poets was crucial. Already in 1953, a selection of his poetry translated by Grigory Gorsky (Григорий Горский) was published in Riga. ${ }^{24}$ Gorsky was a member of the Bolshevik Party and a war correspondent. He had been living and working in Latvia since 1945 as a journalist of the Soviet information agency TASS. Gorsky was also a poet. He continued his work, and in 1961 a complete Russian edition of Veidenbaums's poems was published in Moscow. ${ }^{25}$ In a period when Latvian literature was translated in a great hurry due to the ideological pressure and therefore frequent careless attitude, Gorsky's translations were praised as one of the best.

In 1980, another compilation of poetry by Veidenbaums in a separate edition in the translation of Leonid Cherevichnik (Леонид Черевичник) was published. ${ }^{26}$ Born in Ukraine and living in Riga since 1964, Cherevichnik was a long-time head of the poetry section of the Latvian-Russian literary magazine “Даугава" (1979-1996). Cherevichnik's translations were acknowledged in Latvia as professional. They were also praised by Rolfs Ekmanis in the Latvian exile press - in the journal of the World Federation of Free Latvians (PBLA). ${ }^{27}$ This recognition during the Soviet era cannot be underestimated.

Translations into other languages were sporadic. In the centenary of Eduards Veidenbaums, in 1967 his poems were first translated in Belarusian ${ }^{28}$ and Ukrainian $^{29}$. Ten years later some of Veidenbaums's poems were also included in

17 Латышиске поэты. Рига: Вальтер и Рапа, 1931, с. 9-11.

${ }^{18}$ [Transl. V. K. Matthews]. The Tricolour Sun. Latvian Lyrics in English Version. Cambridge: Heffer, 1936, p. 25.

19 [Trans. E. Stērste]. Poèmes lettons. Rīga: Edité par la Section de la presse au ministère des affaires étrangères de Lettonie 1931, p. 24.

${ }^{20}$ [Trans. Koch]. Sanders, W.; Veidenbaums, E. Weihnachtslied = Sanders, V.; Veidenbaums, Ed. Ziemassvêtku dziesma. [before Ww II].

${ }^{21}$ [Transl. S. Czernik]. Antologia poezji łotewskiej. Ostrzeszow: B-ka okolicy poetow, 1938, st. $26-30$.

22 [Transl. J. Paleckis]. Naujas Žodis 1925, No. 5.

${ }^{23}$ [Transl. N. Kurzēns]. Literatura Mondo, 1934, No. 8.

24 Вейденбаум, Э. Избранное. Рига: Латгосиздат, 1953.

${ }^{25}$ Вейденбаум, Э. Стихотворения. Москва: Государственное издательство художественной литературы, 1961.

26 Вейденбаум, Э. Стихотворения. Рига: Лиесма, 1980.

${ }^{27}$ Ekmanis, R. Dažas iezīmes pēdējo gadu rakstniecībā. Latvija Šodien, 1981, No 9, p. 66.

28 [Transl. A. Bachila (А. Бачыла)]. Лimapamypa i мастачтва, 1967, No. 78, 3. кастр.

${ }^{29}$ [Transl. K. Overchenko (К. Оверченко)]. Літературна Украіна, 1967, о. 39, 3 жовт. 
the anthology of Latvian literature in Hungarian ${ }^{30}$. In Lithuanian Veidenbaums's well-known poem Kā gulbji balti padebeši iet (White clouds are passing like swans) was translated before World War I by the poet Julius Janonis. Unfortunately, it has not survived to nowadays. Estonian translations have been known only since 1967. ${ }^{31}$ However, it is precisely in the Estonian cultural space that the interest in Veidenbaums's poetry has not disappeared. Particularly, a collection of poems Mind ärge lugege (Don't read me) in the translation of Estonian poet Contra (2014) should be noted. ${ }^{32}$

Thanks to Matthias Knoll, Viktors Mel,niks and Vigmantas Butkus for their invaluable help.

${ }^{30}$ [Transl. G. Garai, T. Dezső]. A lett irodalom kistükre. Budapest: Európa könyvkiadó 1977, old.137-141.

31 [Transl. M. Traat, L. Kamara]. Edasi, 1967, No. 243.

${ }^{32}$ Veidenbaums, E. Mind ärge lugege. Pärnu: Jumalikud Ilmutused, 2014. 